\title{
Vitamin K1-containing Urea Skin Cream
}

National Cancer Institute

\section{Source}

National Cancer Institute. Vitamin K1-containing Urea Skin Cream. NCI Thesaurus. Code C96802.

A topical cream containing urea and $0.1 \%$ vitamin K1 (phytomenadione) with topical epidermal growth factor receptor (EGFR)-activating activity. Upon application of vitamin K1-containing urea skin cream, vitamin K1 may locally activate EGFR, thereby abrogating EGFR inhibition in the skin caused by systemic EGFR inhibiting agents. This may help inhibit the acne-like skin rash induced by EGFR antagonists. EGFR, a tyrosine kinase, plays a key role in maintaining epidermal integrity. 